\title{
Kim Knott; Studi Agama Perspektif Insider/Outsider
}

\author{
Uswatul Jannah, \\ uswatuljannah880@gmail.com \\ STIT Aqidah Usymuni Sumenep \\ Ahmad Effendi \\ efendinaa83@gmail.com \\ STIT Aqidah Usymuni Sumenep
}

\begin{abstract}
This paper is the result of a study of Kim Knott's insider / outsider perspective in religious studies. The discussion methodology used in this paper is literature study. This insider / outsider concept was born in order to obtain objective and accountable science of religion. According to Knott, religious researchers must be able to position themselves and understand their position, both as insiders and outsiders. By doing so, it

is also hoped that they will choose the relevant partial approach methodology. The

options Kim Knott offered to insider researchers were a complete participant or participant as observer. Meanwhile, an outsider observer is a complete observer or an observer as a participant. Look at the following schematic:
\end{abstract}

OU T S I D E R I N S I D E R

Complete ------- Observer As Participant Participant As Complete

Observer Observer Participant

Kata Kunci: Insider/Outsider, Studi Agama, Metodologi.

\section{Latar Belakang dan Rumusan Masalah}

Filsafat ilmu dipahami sebagai disiplin filsafat dalam bentuk yang sisitematis mengenai sifat-sifat sain. Baik dari segi konsep dan pemikiran-pemikirannya, metode, dan posisinya dalam skup disiplin-disiplin intelektual. ${ }^{1}$ Cabang filsafat yang kita kenal -salah satunya- dengan epistemologi memainkan perannya sebagai 'penunjuk jalan' bagaiamana sebuah sain dilahirkan dan diperoleh.

\footnotetext{
${ }^{1}$ Amin Abdullah, dkk, Re-Strukturisasi Metodologi Islamic Studies, Cet ke-1 (Yogyakarta: SUKA PressJurnal Al-Jamiah, 2007), hlm 27.
} 
Pun begitu dengan usaha-usaha penelitian dalam skema keagamaan. Dewasa ini, kajian keagamaan semakin diminati banyak kalangan peneliti agama. Sensitifitas dan kompleksitas sebuah agama menjadi tantangan tersendiri dalam rangka menghasilkan disiplin ilmu baru serta sumbangsih intelektual dalam ranah keagamaan. Merupakan permasalahan yang niscaya dalam sebuah kajian agama kemudian, adalah subyektifitas dan obyektifitas. Terdapat korelasi yang kuat antara posisi peneliti sebagai insider (orang dalam) dan peneliti sebagai outsider (orang luar) dalam menjamin dua hal tersebut.

Memang sulit menjadikan agama sebagai kajian. Setidaknya dalam kasus ini ada dua hal menurut Wardenburgh. Pertama, posisi objektif yang wajib dimiliki pengkaji tanpa menturutkan pengalaman keagamaanya (involved). Kedua, anggapan pelecehan, perusakan, dan pengahancuran tata nilai jika mengingat agama adalah hal yang sakral, agung, dan suci bagi pemeluknya. ${ }^{2}$

Maka untuk menghindari kesalahan-kesalahan yang lalu, Kim knott memberikan tawaran baru. Menurutnya ada empat tingkat partisipasi peneliti sebagai observasi dalam kajian pengembangan interkoneksi sosial keagamaan, antara lain partisipan murni (complete participant), peneliti sebagai partisipan (observer as participant), partisipan sebagai peneliti (participant as observer), dan peneliti murni (complete observer).

Untuk lebih memahami konsep pemikiran insider dan outsider-nya Kim Knott, kita akan bahas dalam kajian ini dengan mengacu pada permasalahan sebagai berikut:

1. Apa yang melatarbelakangi munculnya teori Kim Knott mengenai perspektif insider dan outsider dalam studi agama?

2. Bagaimana pandangan Kim Knott tentang perspektif insider dan outsider dalam studi agama?

\footnotetext{
${ }^{2}$ Ahmad Norma Permata, Metodologi Studi Agama, (Yogyakarta: Pustaka Pelajar, 2000), hlm. 13-14.
} 
Tafhim Al-'Ilmi : Jurnal Pendidikan dan Pemikiran Islam Terakreditasi Nasional SK No : 148/M/KPT/2020
ISSN: 2252-4924, e-ISSN: 2579-7182

Volume 12, No. 1 September 2020

\section{Kerangka Teori}

Kerangka teori yang digunakan adalah (a) pengertian agama (b) pengertian insider dan outsider secara umum.

a. Pengertian Agama

Pengertian atau definisi adalah tolok ukur bagaiamana seorang ilmuwan membatasi ruang lingkup kajian sehingga dapat fokus pada masalah yang dikaji. Sedangkan agama sendiri memiliki makna yang luas dalam kaitannya dengan definisi agama menurut bahasa, menurut ilmu sosial (subtantif, fungsional), menurut simbolis, dan sosio-kultural Indonesia. Sangat sulit mengemukakan definisi yang pas dan sempurna untuk agama.

Agama menurut pengertian bahasa dapat disejajarkan dengan istilah religion dalam bahasa Inggris. Menurut asal katanya, religion berasal dari istilah latin religio yang berarti pendeta atau bapa yang berhak menyatakan benar dan salah menurut suatu sistem keyakinan tertentu. ${ }^{3}$

Dalam istilah Indonesia asli maupun istilah-istilah lokal etnis di Indonesia, pengertian istilah religi sangat sulit ditemukan padanannya. Pengertian religi yang kemudian dapat disejajarkan dalam bahasa Indonesia adalah menurut KBBI yang berarti segenap kepercayaan (kepada Tuhan, Dewa, dsb) serta dengan ajaran kebaktian dan kewajiban-kewajiban yang bertalian dengan kepercayaan itu.

b. Pengertian Insider dan Outsider secara umum.

Pengertian insider dan outsider secara umum bahwa Insider adalah para pengkaji agama yang berasal dari agamanya sendiri. Artinya, satu agama dengan agama yang dikaji, disebut juga orang dalam. Sedangkan outsider adalah para

\footnotetext{
${ }^{3}$ Fionna Bowie, The Anthropology of Religion (Massachusetts:Blackwell Publisher, 2000), hlm ?
} 
pengkaji agama yang meneliti agama lain, disebut pula degan orang luar. Dalam istilah antropologi insder dan outsider sama halnya dengan emik dan etik. Emik dan etik adalah istilah yang digunakan antropolog bidang ilmu sosial dengan merujuk pada dua pola perilaku manusia. Istilah ini khusus digunakan dalam antropologi budaya untuk merujuk pada jenis lapangan dan sudut pandang yang diperoleh. Emik merupakan deskripsi tentang perilaku atau keyakinan. Hampir semua hal dari suatu budaya dapat memberikan emik. Sedangkan etik adalah gambaran tentang perilaku atau kepercayaan pengamat.

Istilah emik-etik ini pertama kali diperkenalkan pada tahun 1954 oleh ahli bahasa Kenneth L. Pike. Menurutnya, emik sama halnya dengan kajian kepribadian yang lahir dari insider, sedangkan perspektif etik muncul dari outsider. Secara singkat emik mengacu pada pandangan warga masyarakat yang dikaji, sedangkan etik mengacu pada pandangan si peneliti. Konstruksi emik adalah deskripsi dan analisis yang dianggap bermakna bagi partisipan. Sedangkan konstruksi etik merupakan deskripsi dan analisis yang dianggap bermakna oleh pihak luar sebagai komunitas ilmiah yang kritis.

\section{Metode Pengkajian}

Kajian epistemologi Kim Knott ini menggunakan metodologi kualitatif dengan rujukan utama tulisan Knott yang berjudul Insider/Outsider dalam John R. Hinnells (ed.), The Routledge Companion to the Study of Religion. Dalam rangka menguatkan pemahaman terhadap karya tersebut, terdapat 25 buku pendukung yang membahas tema serupa dan terkait. Baik dalam bentuk konvensional maupun elektronik. Beberapa di antara buku tersebut adalah Religious Studies Problem Hubungan Islam dan Barat Kajian atas pemikiran Karel A. Steenbrink karya Muhammad Muslih dan Jika Sains Mencari Makna karya Louis Leahy.

\section{Konsep Dasar}

Landasan awal dari penulisan makalah ini adalah tentang konsepsi posisi peneliti, baik sebagai Insider/Outsider dalam menentukan hasil kajian. Kemampuan objektifitas peneliti insider dan outsider dalam ekplanasi penilaiannya harus 
Tafhim Al-'Ilmi : Jurnal Pendidikan dan Pemikiran Islam Terakreditasi Nasional SK No : 148/M/KPT/2020
ISSN: 2252-4924, e-ISSN: 2579-7182

Volume 12, No. 1 September 2020

menjadi perhatian. Apalagi jika objek kajian adalah agama, dimana setiap peneliti memiliki latar belakang dan jerat historis agamis yang melekat pada mereka. Sehingga dimungkinkan terjadi kerancuan data, antara agama lain yang sedang dikaji serta pengalaman agamanya sendiri. Berbeda halnya jika sang peneliti mengkaji agama yang sama dengan agama yang diteliti. Unsur subjektifitas memiliki peluang besar di sini.

Maka dibutuhkan metodologi yang jelas dalam rangka menjamin keabsahan kajian. Baik melalui direct research (berbaur dengan objek) atau indirect research (data dari narasumber).

\section{Pembahasan}

a. Biografi Intelektual

Kim Knott merupakan sosok peneliti yang fokus pada pengembangan metodologi spasial dalam studi agama. Tujuan Knott untuk mencari keterlibatan sirkuler antar agama, baik sosial, budaya, politik, ekonomi dan lainnya. Dalam The Location of Religion: A Spatial Analysis ${ }^{4}$ ia menyatakan bahwa penerapan teori sosio-spasial dalam studi agama, mempunyai korelasi positif dalam tataran implementasi ajaran agama.

Ditingkat regional, Knott duduk sebagai Sekretaris Jenderal Asosiasi Eropa untuk Studi Agama. Ia juga merupakan dosen senior pada Studi Agama di University of Leeds, Inggris. Posisi inilah yang membawanya menjadi peneliti garda depan tentang agama-agama dan mengantarkannya sebagai penulis produktif pada sejumlah jurnal tentang gerakan-gerakan agama kontemporer di London.

Selain itu Knott memfokuskan penelitiannya pada agama dan nilai-nilai universal dalam ranah sosio-kultural masyarakat dan hubungannya dengan fenomenologi agama. Bersama Thomas A. Tweed, ia bekerja pada sebuah perpustakaan bidang geografi agama. Di University of Leeds, Knott adalah Direktur

\footnotetext{
${ }^{4}$ Kim Knott, The Location of Religion, a Spatial Analysis (UK London: Equinox Publishing, 2005), hlm 57.
} 
Tafhim Al-'Ilmi : Jurnal Pendidikan dan Pemikiran Islam Terakreditasi Nasional SK No : 148/M/KPT/2020
ISSN: 2252-4924, e-ISSN: 2579-7182

Volume 12, No. 1 September 2020

Riset, Seni, dan Humaniora pada program Dewan Diaspora, Migrasi, dan Identitas Agama. Ia juga co-editor bersama McLoughlin dalam sebuah jurnal Diaspora.

Sebagai Profesor Studi Agama dan Direktur Komunitas Antar Agama, Knott menulis tentang agama di Inggris, yang meliputi identitas agama-agama modern dan isu-isu metodologis tentang studi agama. Kegiatan akademiknya termasuk membantu mahasiswa menjadi peneliti yang kompeten dengan mengangkat isu-isu agama yang lebih luas. Saat ini ia memfokuskan penelitiannya pada agama di dua organisasi publik: institusi universitas dan kelompok masyarakat.

Dalam penelitiannya Knott banyak menggunakan pendekatan teoritis dan induktif berdasar pada budaya lokal. Titik awal dalam mengembangkan pendekatan spasial tersebut adalah theories of place yang dikembangkan oleh Heidegger, Edward Casey dan Christopher Tilley. Sebagai seorang feminis dan kritikus postmodern, hal itu mengantarkannya untuk mempertanyakan wacana yang kemudian membuatnya menekuni kajian keagamaan dengan pendekatan geografis dan studi agama-agama.

Realitas di atas merupakan pendekatan awal yang diidentifikasi oleh Knott untuk dapat diterapkan pada lokus agama. Pada bagian berikutnya ia merujuk ke pelbagai sumber dalam studi agama, sebelum menunjukkan bagaimana metode spasial dapat diterapkan sehingga merefleksikan kekuatan dan kelemahannya secara konkret. Menurut Knott, agama harus bekerja dalam parameter ini, karena ia dibentuk berdasarkan titik awal dengan pendekatan spasial.

Sejak tahun 2005 Knott banyak menelurkan karya-karya tulisnya, seperti buku The Location of Religion: A Spatial Analysis (Equinox: 2005) dan Temenos: The Nordic Journal of Comparative Religion. Pun beberapa proyek kolaborasi lainnya semisa karya Iconic Religion: How Imaginaries of Religious Encounter Structure Urban Space. Sebelum ini Knott juga banyak meneliti tentang Hinduism A Very Short Introduction (OUP:1998, 2000) dan Hinduism in Leeds: Religious Practice in Indian Hindu Communities and Modern Hindu Movements (CRP: 1986). 
Tafhim Al-'Ilmi : Jurnal Pendidikan dan Pemikiran Islam Terakreditasi Nasional SK No : 148/M/KPT/2020
ISSN: 2252-4924, e-ISSN: 2579-7182

Volume 12, No. 1 September 2020

b. Latar Belakang Pemikiran Kim Knott Tentang Insider dan Outsider dalam Studi Agama

Sejak awal karirnya, Knott sudah menunjukkan interest yang tinggi terhadap bidang studi keagamaaan. Disokong pula dengan berbagai posisi elit yang kesemuanya bergerak di bidang agama, menjadikan Knott semakin produktif. Keterlibatannya dalam beberapa proyek penelitian kelas tinggi bersama orang-orang ternama pula tentu semakin menaikkan popularitas keilmuan Knott di kalangan para pengkaji. Banyak sekali temuan-temuan baru yang disodorkan Knott terhadap teoriteori agama, termasuk metodologi studi agama itu sendiri seperti konsep insider dan outsider.

Dalam mengkaji persoalan agama, Knott menelaah sejumlah karya peneliti sebelumnya, seperti Kristensen, Van der Leeuw, Rudolf Otto, Mircea Eliade, Wilfred C. Smith, Cornelius Teile, Kenneth Pike dan Ninian Smart. Dari karyakarya itu, Knott membuat pemetaan terhadap pendekatan studi agama. Knott mencoba memberikan penawaran baru terhadap studi agama. Menurut Knott, metode-metode terdahulu masih belum bisa menampakkan obyektifitas.

Gagasan Knott tentang insider dan outsider ini diawali dengan problematika keaagamaan yang dialami oleh mahasiswa studi pengembangan pemahaman agama, tempat Knott mengajar. Mereka diberi tugas meneliti tentang riwayat orang-orang beragama, padahal dalam posisi outsider. Namun seketika mereka bisa menjadi insider ketika mereka memiliki pengalaman subjektif sendiri mengenai agama yang yang mereka teliti.

Berbagai pertanyaan pun muncul selama kajian tersebut berlangsung; mampukah orang luar memahami secara mendalam tentang pemahaman keagamaan seseorang? Apa bedanya antara persepsi insider dan insider mengenai agama? Adakah gap pemisah antara orang yang menulis riwayat hidup (pengalaman keagamaan) dengan mereka yang membaca riwayat hidup (pengalaman agama) orang lain? 
Melihat hal diatas berarti ada beberapa kegelisahan akademik Kim Knott yang dapat dipetakan. Pertama, sangat sulit membuat batas antara wilayah agama dan yang bukan. Kedua, adanya kesulitan antara memahami agama sebagai tradisi dan keimanan. Ketiga, terjadinya stagnasi metodologis dan pendekatan dikalangan akademisi mengenai agama. Mereka dituntut se obyektif mungkin dalam memahami agama, disisi lain mereka harus meletakkan agama dalam nilai transendensi yang harus di junjung tinggi.Tapi yang menjadi pokok permasalahan utama adalah objektifitas, inilah kegelisahan akademik Knott.

c. Perspektif Kim Knott Terhadap Insider/Outsider dalam Studi Agama

Diskursus tentang insider dan outsider ini muncul ke permukaan pada pertengahan 1980-an ketika terjadi debat panas tentang studi Sikhisme: kontribusi, dan motivasi utama ilmuwan dalam mengkaji Sikh religion ini. Banyak yang mempertanyakan keabsahannya: tentang siapakah yang dapat memahami dan mewakili Sikh tradition, apakah motivasi personal dan sudut pandang epistemologi serta kepentingan ideologis para pengkaji tersebut?

Kim Knott menyatakan bahwa pengalaman keagamaan yang ada dalam diri insider ditampilkan dan kemudian direspon oleh outsider. Namun tetap dengan mempertimbangkan batas-batas objektivitas dan subjektivitas yang terjadi dalam pengalaman keagamaan dan didasari oleh sikap empati dan analisis kritis. Pada titik ini, insider-outsider saling berbagi keseimbangan perspektif dalam sejarah studi agama.

Jauh sebelumnya, Max Muller (1873) telah mempertegas bahwa sebagai objek studi, agama harus ditampilkan secara proporsional, meski ia juga harus dikritisi. Dua puluh tahun kemudian, Cornelius Tiele menekankan kepada para ilmuwan untuk melakukan penelitian dengan mengedepankan objektivitas tanpa menjadi skeptis, melalui studi dan investigasi yang tidak memihak. ${ }^{5}$ Ia juga membedakan antara subjektivitas keagamaan pribadi individu dan objektivitas cara pandang terhadap agama orang lain.

\footnotetext{
${ }^{5}$ Nourouzzaman Shiddiqi, Sejarah: Pisau Bedah Ilmu Keislaman dalam Taufik Abdullah (ed.), Metodologi Penelitian Agama: Sebuah Pengantar (Yogyakarta: Tiara Wacana, 1991), hlm 58.
} 
Selanjutnya, pelbagai isu seputar studi agama diberi penguatan metodologis, terutama yang berkaitan dengan fenomenologi agama, sebagaimana yang dilakukan oleh Kristensen, Van der Leeuw dan Rudolf Otto di Jerman, kemudian Mircea Eliade dan Wilfred Cantwell Smith di Amerika serta Ninian Smart di Inggris. Mereka menyatakan bahwa semua agama merupakan fenomena unik yang dapat dilihat dari pelbagai sisi (multi faces), otonom dan tak ada bandingannya, namun mampu memberikan pemahaman secara empatik. Tujuan yang mendasari pendekatan fenomenologis adalah untuk mengerti dengan penuh empati berdasarkan pada pengalaman insider, disamping kemampuan menahan diri dari penilaian negatif prejudice yang muncul dari outsider. ${ }^{6}$

Dalam beberapa dekade terakhir, dua pendekatan yang agak berbeda dalam mempelajari agama telah muncul di Barat. Salah satunya adalah scientific method. Bercampurnya antara agama dan sosio-historis-kultural atau antara yang sakral dan yang profan tidak mudah lagi dibedakan. Jika dalam wilayah keilmuan biasa, para ilmuwan masih bisa membuat distingsi antara pure science yang inklusif dan applied science yang eksklusif, namun dalam wilayah keilmuan agama sulit untuk membuat titik pemisah antara keduanya. ${ }^{7}$ Memang, sebagaimana dinyatakan oleh Arkoun, unsur sakralitas (taqdis al-afkar al-diniyyah) yang termuat dalam agama menambah rumitnya persoalan. Dalam hal ini, sering didapati, bahwa wilayah perbincangan keagamaan yang semula bersifat profan menjadi disakralkan.

Berbeda dengan Knott, Charles S. Pierce mengajukan konstruksi pemikiran sebagai basis studi agama. Pertama, belief, yang berupa tatanan sosial yang dipegang secara absolut dan dipadu oleh tatanan kekuatan moral. Kedua, habit of mind, yakni tradisi yang turun temurun dan telah mengkristal menjadi kebiasaan dalam pelbagai aspek kehidupan. Ketiga, doubt, mempertanyakan tentang apa yang selama ini dianggap menjadi mainstream pemikiran dan pengejawantahan. Untuk memperoleh keyakinan, menurut Pierce, seorang peneliti harus melakukan empat tahapan pertimbangan guna mengurai doubt menjadi potensi positif argumentatif:

\footnotetext{
${ }^{6}$ William Brede Kristensen, , The Meaning of Religion (The Hague: Martinus Nijhoff, 1960) hlm 391.

${ }^{7}$ Josef Van Ess, The Logical Structure of Islamic Theology dalam Issa J. Boullata (ed.), An Anthology of Islamic Studies (Canada: McGill Indonesia IAIN Development Project, 1992), hlm 24.
} 
Tafhim Al-'Ilmi : Jurnal Pendidikan dan Pemikiran Islam Terakreditasi Nasional SK No : 148/M/KPT/2020
ISSN: 2252-4924, e-ISSN: 2579-7182

Volume 12, No. 1 September 2020

tenasitas, otoritas, apriori dan investigasi. Keempat, Inquiry (penelitian). Meski demikian ia menegaskan bahwa yang dicari adalah meaning (nilai), bukan truth (kebenaran), yang merupakan teori pemaknaan pragmatis namun operatif. ${ }^{8}$ Kelima, the logic of theory, sebagai landasan aplikasi kajian.

Russell McCutcheon mencoba memberi penguatan guna melakukan kategorisasi tanggapan insider ke outsider dalam empat dimensi: (i) otonomi pengalaman religius yang terkait dengan pendekatan fenomenologi, (ii) reduksionisme yang dicontohkan oleh komunitas akademisi yang mengambil suatu sikap ilmiah, (iii) netralitas dan metode agnostisisme, seperti yang diadopsi oleh Ninian Smart yang mengandalkan ikon outsider dengan mengidentifikasi kebenaran dari perspektif orang lain (iv) refleksifitas.

Dalam wilayah studi agama, usaha yang ditempuh dengan pendekatan sosial ialah memahami agama secara objektif dan signifikansinya dalam kehidupan masyarakat. Tujuan dari pendekatan ini guna menemukan aspek empirik keberagamaan berdasarkan keyakinan bahwa dengan membongkar sisi empirik agama akan membawa seseorang kepada agama yang lebih sesuai dengan realitasnya.

Menurut Knott, sebagaimana dikutip dari Charles J. Adams, dalam hal ini diperlukan pendekatan fenomenologi. Metode untuk memahami bagaimana agama seseorang mengkaji pilihan dan komitmen mereka secara netral, sebagai persiapan untuk melakukan rekonstruksi pengalaman orang lain. Konstruksi skema taksonomik untuk mengklasifikasikan fenomena dihadapkan pada batas-batas budaya dan pengalaman keagamaan. Jadi secara umum, pendekatan ini hanya menangkap sisi pengalaman keagamaan dan kesamaan reaksi keberagamaan manusia tanpa memperhatikan dimensi ruang dan waktu serta perbedaan budaya masyarakat.

Dalam Spatial Theory-nya Kim Knott tentang insider dan outsider - Amin menyebutnya dengan istilah space of in dan space of out untuk memposisikannya,

\footnotetext{
${ }^{8}$ Milton K. Munitz, Contemporary Analytic Philosophy (New York: Macmillan Publishing Co Inc, 1976), hlm 403.
} 
Tafhim Al-'llmi : Jurnal Pendidikan dan Pemikiran Islam Terakreditasi Nasional SK No : 148/M/KPT/2020
ISSN: 2252-4924, e-ISSN: 2579-7182

Volume 12, No. 1 September 2020

di antara keduanya ada ruang yang disebut dengan istilah space of between ${ }^{9}$ - , model insider terbagi menjadi dua, yaitu participant as observer dan complete participant, sedangkan model outsider-nya juga terbagi menjadi dua, yaitu complete observer dan observer as participant.

1) Partisipan murni (Complete Participant)

Para partisipan murni adalah para sarjana yang menulis tentang agamanya sendiri. Seperti sarjana teologi, pendeta, kiyai, mufti, dan sebagainya. Bagi mereka objektifitas bukan hal utama. Tujuan dari penulisan itu adalah untuk memantapkan keyakinan serta mengembangkan pengetahuan mereka tentang agama yang diyakini. Knott menyontohkan Fatimah Mernisi dalam kasus ini. Mernisi adalah insider yang kritis terhadap Islam. Ia menuliskan sebuah gagasan yang bertujuan meluruskan dan memperjuangkan hak-hak muslimah yang kelam.

Meski tindakan Mernisi menuai banyak cibiran dan dituduh pembohongan syari'at, ia tetap gencar menyuarakan gagasannya. Menurutnya, konsep demokrasi, hak asasi manusia, kebebasan, dan partisipasi dalam panggung politik bukan diadopsi dari barat, melainkan nilai islam sendiri. Dalam kutipan yang diambil Knott dari tulisan Mernisi menyebutkan:

We muslim women can walk into modern world with pride, knowing that the quest for dignity, democracy, and human right, for full participation in the political and social affairs of our country, stems from no imported western values, but is true part of the muslim tradition. ${ }^{10}$

2) Partisipan Sebagai Peneliti (Participant as Observer)

Peneliti adalah anggota aktif kelompok dan secara aktif berpartisipasi dalam aktivitas kelompok dan berinteraksi. Setiap anggota mengetahui bahwa selain si

\footnotetext{
${ }^{9}$ M. Amin Abdullah, The Textual-Theological and Critical-Philosophical Approach to Morality and Politics: A Comparative Study of Ghazali and Kant, dalam Diskursus: Jurnal Filsafat dan Teologi, Vol. 4, No. 2, Sekolah Tinggi Filsafat Driyarkara, Juni 2005, hlm 151.

${ }^{10}$ Kim knott, Insider / outsider dalam John R. Hinnells, The Routledge Companion to the Study of Religion (London: Routledge Taylor and Fancis Group, 2005), ), hlm 244.
} 
partisipan juga berperan sebagai peneliti. Esensinya, sebuah hubungan kolaboratif dikembangkan antara pengamat dan partisipan. Pada saat mereka melakukan studi agama, maka yang dimunculkan adalah prinsip-prinsip penelitian ilmiah sosial: objektivitas, netralitas, dan mutual konsultasi untuk membuktikan kebenaran hasil dari kajian mereka. Namun Festinger memutuskan bahwa pendekatan semacam itu tidak dapat digunakan untuk mengkaji perilaku keberagamaan seseorang.

Pada kenyataannya, apa yang mereka lakukan adalah menunggu tanda-tanda dari kelompok keberagaman, kemudian mengamati prilaku komunitasnya dari dalam. Mereka menerapkan peran insider untuk untuk observasi sebagai pencari realitas tak langsung. Sehingga akan didapat hasil yang lebih akurat. Dengan demikian, mereka menyadari adanya kebutuhan untuk memenuhi kondisi sosial, khususnya ketika tidak mampu tampil sebagai subjek anggota kelompok. Dengan ini terbukti betapa sulitnya bagi peneliti untuk tidak terlibat dan tidak memihak ketika melakukan penelitian pada subjek agama apapun.

\section{3) Peneliti Sebagai Partisipan (Observer as Participant)}

Peranan pengamat secara terbuka diketahui oleh umum, karena segala macam informasi termasuk yang rahasia dengan mudah dapat diperoleh. Memilih model pendekatan ini sedikit menghilangkan partisipasi peneliti dari anggota kelompok. Walaupun dia masih memiliki hubungan dengan kelompok tersebut, tapi tidak berpartisipasi aktif dalam kelompok.

Penelitian dengan model complete observer yang sembunyi-sembunyi ditolak oleh Eilen Barker. Baik dengan alasan praktis ataupun etis. Menurut Barker dengan menjadi partisipan akan didapat banyak sekali kemudahan dalam meneliti. Barker sendiri ketika meneliti kaum moonie (persekutuan gereja) menjadi partisipan di dalamnya. Dia tinggal di pusat gereja dan berbincangbincang dengan anggotanya. Mendengarkan sekaligus mengajukan pertanyaanpertanyaan yang seharusnya hanya boleh ditanyakan anggota Moonie. 
Dengan masuk sebagai anggota Moonie, ia berhak mendengar dan bertanya. Selain itu, mantan anggotanya pun menjadi sasaran data Barker. Anggota yang sudah keluar biasanya memiliki hubungan buruk dengan tokoh ataupun instansi dalam persekutuan gereja. Ini dimanfaatkan Barker untuk mengetahui kelemahan-kelemahan Moonie. Sama halnya dengan pola pendekatan Mark Weber dan Niniam Smart yang turut menginspirasi Barker. Bahkan pada era 1970-an - 1780-an metode ini mendominasi studi keagamaan.

\section{4) Peneliti Murni (Complete Observer)}

Adalah para sarjana yang meneliti keagamaan sepenuhnya dari luar, tanpa terlibat apapun terhadap agama yang ditelitinya. Jenis ketiga ini biasanya dalam bidang sosiologi dan psikologi agama. Layaknya wawancara, peneliti menyusun pertanyaan-pertanyaan terstuktur terhadap narasumber, informan, dan respondennya. Jawaban-jawaban tersebut kemudian dianalisis menggunakan frame keilmuan tertentu. Festinger, Riecken, dan Schaster telah melakukannya pada tahun $1956 .^{11}$

Prinsip dasar dalam perspektif ini adalah netralitas, objektifitas, validitas, dan generalisasi dari hasil kajian, sebagaimana perspektif etik. Maka dalam prosesnya, insider sebagai informan tidak boleh tahu tentang adanya penelitian ini. Sehingga tidak ada rekayasa oleh kelompok yang diteliti.

OU T S I D E R

Complete

Observer
Observer As Participant
Participant As

Observer
I N S I D E R

Complete Participant

\section{Simpulan}

Sifat agama yang multi-faces melahirkan tawaran-tawaran baru dalam metodologi pendekatan studi keagamaan. Ketidakmampuan model-model terdahulu dalam menyajikan kajian yang obyektif dan tidak memihak, telah menarik Kim Knott - profesor religious studies - untuk menciptakan teori parsial kajian

\footnotetext{
${ }^{11}$ Kim knott, Insider / outsider, hlm 249.
} 
Tafhim Al-'Ilmi : Jurnal Pendidikan dan Pemikiran Islam Terakreditasi Nasional SK No : 148/M/KPT/2020
ISSN: 2252-4924, e-ISSN: 2579-7182

Volume 12, No. 1 September 2020

keagamaan yang dikenal dengan perspektif insider dan outsider, guna mengoreksi kekurangan-kekurangan penelitian sebelumnya.

Knott memandang bahwa dalam rangka mengusahakan obyektifitas dan netralitas, peneliti harus menempuh pendekatan berikut: model complete participant (partisipan murni) dan participant as observer (partisipan sebagai peneliti) bagi insider, dan model complete observer (peneliti murni) dan observer as participant (peneliti sebagai partisipan) bagi peneliti outsider.

\begin{tabular}{|c|c|c|}
\hline OU T S I D E R & & \\
\hline $\begin{array}{l}\text { Complete } \\
\text { Observer }\end{array}$ & $\begin{array}{l}\text { Observer As } \\
\text { Participant }\end{array}$ & $\begin{array}{l}\text { Participant As } \\
\text { Observer }\end{array}$ \\
\hline
\end{tabular}

\section{Daftar Pustaka}

Abdullah, Amin dkk, Re-Strukturisasi Metodologi Islamic Studies, cet ke-1. Yogyakarta: SUKA Press-Jurnal Al-Jamiah, 2007.

Permata, Ahmad Norma, Metodologi Studi Agama. Yogyakarta: Pustaka Pelajar, 2000.

Bowie, Fionna The Anthropology of Religion. Massachusetts:Blackwell Publisher, 2000 .

Poerwadarminto, 1984

Knott, Kim The Location of Religion, a Spatial Analysis. UK London: Equinox Publishing, 2005

Shiddiqi, Nourouzzaman, Sejarah: Pisau Bedah Ilmu Keislaman dalam Taufik Abdullah (ed.), Metodologi Penelitian Agama: Sebuah Pengantar. Yogyakarta: Tiara Wacana, 1991.

Kristensen, William Brede, The Meaning of Religion. The Hague: Martinus Nijhoff, 1960.

Ess, Josef Van, The Logical Structure of Islamic Theology dalam Issa J. Boullata (ed.), An Anthology of Islamic Studies. Canada: McGill Indonesia IAIN Development Project, 1992. Milton K. Munitz, Contemporary Analytic Philosophy. New York: Macmillan Publishing Co Inc, 1976.

Abdullah, M. Amin, The Textual-Theological and Critical-Philosophical Approach to Morality and Politics: A Comparative Study of Ghazali and Kant, dalam 
Tafhim Al-'Ilmi : Jurnal Pendidikan dan Pemikiran Islam Terakreditasi Nasional SK No : 148/M/KPT/2020
ISSN: 2252-4924, e-ISSN: 2579-7182

Volume 12, No. 1 September 2020

Diskursus: Jurnal Filsafat dan Teologi, Vol. 4, No. 2, Sekolah Tinggi Filsafat Driyarkara, Juni 2005.

knott, Kim, Insider / outsider dalam John R. Hinnells, The Routledge Companion to the Study of Religion. London: Routledge Taylor and Fancis Group, 2005. 